\title{
Implementation of the state policy on children in Tula oblast
}

\author{
Nadezhda Anatolievna Shaidenko ${ }^{1 *}$, Elena Yakovlevna Orekhova ${ }^{2}$, and Svetlana Nikolaevna \\ Kipurova $^{1}$ \\ ${ }^{1}$ The Advanced Training and Professional Retraining Institute of Education Professionals of Tula \\ Region, Center for the Strategic Planning of the Education Development, Expertise and Scientific \\ Advice, Tula, Russia \\ ${ }^{2} \mathrm{MCU}$, Institute of Foreign Languages, Department of French Language and Linguodidactics, \\ Moscow, Russia
}

\begin{abstract}
The profound and comprehensive crisis faced by the Russian Federation in the 1990s severely affected families and children. With the advent of the new millennium, however, funding for all aspects regarding family and children increased and the role and responsibilities of state agencies were enshrined in legislation. The change in interpersonal relations, women's employment, and the focus on reducing the number of orphanages through various forms of foster care support the need for new ideologies and measures to support families and orphans and children left without parental care. This supports the importance of analyzing the regional policy in the sphere of family and orphans based on the state legislation on the one hand and the regional normative legal documents stemming from this experience on the other. The study uses the methods of specific sociological techniques: surveying, content analysis of the regional press on the problems of the social sphere, and analysis of legislative and regulatory documents and statistical data. The article identifies the problems present in education in the studied region, as well as significant positive changes primarily in rehabilitation work with parents deprived of parental rights to return children to their families. The authors propose a strategy for early prevention of family dysfunction based on increased cooperation between all regional subjects of upbringing. Forms of socio-pedagogical support for families with foster children are highlighted separately. The main reason for the continuing problems in the region is the lack of activity on the part of most social systems having the potential of pedagogical impact. In terms of future perspectives, the authors indicate the need to develop educational and developmental multivariate programs focused on the development of competent parenthood in the region.
\end{abstract}

Keywords: state policy, family education, childhood sphere, parenthood, orphans, socio-economic factors, regional approach, regulatory and legal documents, compliance with the law.

\footnotetext{
* Corresponding author: nashaidenko@gmail.com
} 


\section{Introduction}

The key contemporary ideas of family and public upbringing focus on organizing a qualitatively effective interaction between all actors involved in education, as well as creating a single open socio-cultural space of education. Firstly, this implies a new understanding of the quality of parenthood based on the differentiated approach to competency-based parenting and the recontextualization of this phenomenon considering regional socioeconomic factors, and secondly, necessitates the development of basic directions and public intentions in improving the quality and conditions of life of orphans in each particular region of the country [1].

The goal of the study is to analyze foreign and Russian research on the problems of modern families, reasons for family crises, the essence of orphanhood, particularly social orphanhood, and characterize the situation in one of the prosperous Russian regions, Tula Oblast, on this basis.

"The essence of the modern stage lies in the erosion of the family ideal... the number of epithets of the modern family is quite large... Thus, it is important to recognize that the essence of the crisis of normativity is not in the expansion of family practices themselves but in the expansion of the number of family images that set (configure) the real family practices" $[2]$.

At the theoretical and practical levels, the actualization of the problem of competencybased parenting in modern society takes the form of contradictions. These contradictions are global and are noted by researchers in different countries since the crisis of the family is a characteristic feature of the reality of the 21 st century [3]. This is evidenced by the results of both foreign and Russian research [4-6]. Researchers note that "the changed structural conditions and liberalization of gender relations shape the demand for new ideologies and family support measures adequate to the demand from working adults interested in the optimal combination of their professional, family, and parental responsibilities" [7]. A large number of orphaned children has grown to become a great problem [8].

The modern approach to the interaction of public and family upbringing is due to significant changes in the Russian education system [9]. The transformation of educational landscapes provides for the unification of all scientific and cultural, scientific and educational, and pedagogical spaces through mutually beneficial coordination of efforts between the subjects of upbringing, and the ongoing changes open up new opportunities for the upbringing of orphans and children left without parental care.

\section{Methods}

The conducted study results in the analysis of priority directions in the sphere of childhood, the real potential of socio-cultural interaction of the subjects of upbringing in Tula Oblast in the interests of the development of orphans and children left without parental care to ensure children's welfare at the family level with the participation of various actors of social systems. Note that here we consider both orphans in orphanages and children in foster care or under guardianship.

Empirical data was collected using the methods of specific sociological techniques: surveying, content analysis of the regional press on the problems of the social sphere, and analysis of legislative and regulatory documents and statistical data. 


\section{Results}

Tula Oblast is implementing "The strategy for action in the interest of children of Tula Oblast in 2012-2017" [10] specifying the main directions and tasks of state policy in the interests of children and the key mechanisms for its implementation at the regional level. The document is based on universally recognized principles and norms of international law. The Tula Oblast Regional Strategy notes that all priorities focus on creating a comfortable and child-friendly environment.

Tula Oblast is a region with a predominance of rural schools. Specifically, $46.4 \%$ of institutions responsible for $85.3 \%$ of children are located in cities and $53.6 \%$ of institutions responsible for $14.7 \%$ of children are located in rural areas.

Of particular concern to teaching staff are families (mostly rural) characterized by not only the parents being unaware of their problems but also the conditions being severe to the point of threatening children's lives and health. According to teachers' observations, due to their anti-social or criminal lifestyle, parents typically do not create the basic conditions for the upbringing of children and allow cruel treatment of children. Such parents are most often deprived of parental rights. Most certainly, it is only possible to help children from such families with the close cooperation of all the subjects of upbringing including social workers, employees of Juvenile Affairs Units, and representatives of law enforcement agencies. Although most teachers are dissatisfied with parents' participation in the upbringing and education of their children, all educational institutions of Tula Oblast do carry out special work with parents aimed at developing self-government in the class parent group and increasing the role and status of parents and parent communities, as well as psychological and pedagogical education of parents. This involves exploring parents' educational orientations, meeting with specialists from various fields, discussing the problems of raising children, and involving them in extracurricular activities [11].

In the course of the study, the forms of interaction between families with foster children and various social system participants were characterized and the most significant directions projected on the development of the regional system of the upbringing of orphans were outlined. Noteworthy in this aspect is the socio-pedagogical support for families with foster children in Tula Oblast that typically manifests in rehabilitation work aimed at psychological and pedagogical education of families. Researchers note that modern social practice shows that the current system of socio-educational support for families with foster children is not yet sufficiently effective, as evidenced by the persistently high level of children's ill-being in such families. The socio-pedagogical support system's focus on families in difficult life situations is one of the main factors [12]. The current system of socio-pedagogical support for families with children in Tula Oblast is no exception since it is less focused on the prevention function and more so on the rehabilitation function which largely explains its lack of effectiveness. The identification of socially vulnerable groups of families as the main object of support in the new socio-cultural realities leads to the fact that the measures taken are aimed at bringing families with children out of difficult situations and overcoming the negative social phenomena caused by family dysfunction rather than at preventing them [13].

\section{Discussion}

It has been suggested that not all dysfunctional families are included in the field of social support services under the characterized approach; many moments and situations of dysfunction are overshadowed by the overall social adequacy and external success of the family [14]. As a result, a family ceases to perform its basic functions and, even if it retains its actual integrity, begins to destructively affect the processes of self-development, birth. and upbringing of children. In this case, not only the educational institution but also other 
actors of social systems must account for the fact that the object of socio-pedagogical support can and has to be a family of any type [15]. However, the degree of need for this support will vary, as will its specific content and the types of assistance that families of different types need and/or may need.

In Tula Oblast, there is still little demand for opportunities for interaction between other social system participants that have the potential for pedagogical influence. For example, only educational institutions continue to deal with the problems of pedagogically unsound families providing these families with assistance within the limits of their departmental competence. Work with the indicated families requires the creation of a special model focused on the development of competency-based parenting through the interaction of all subjects of upbringing designed to implement a clear sequence of use of various methods and means of early prevention of family dysfunction in this category of families. The overall strategy should include:

- a system of measures to develop work with the family in its natural environment in the sociocultural conditions of the neighborhood;

- expanding the scope of services provided for this purpose particularly through a system of additional joint education for foster children and their parents;

- intensification and expansion of the areas of work with families and children;

- the development of the potential of pedagogical impact possessed by the subjects of upbringing in the modern functioning of regional education.

The aforementioned interaction of all regional subjects of upbringing implies the forms of relations in which the efforts of organizations (including, first and foremost, children's and parents" communities) are united to achieve the common goals in the interest of families and children.

\section{Conclusion}

In recent years, the regional policy of Tula Oblast in the interests of the family, as well as the implemented municipal targeted programs, have brought the problem of orphans and children left without parental care in the region up to date. This necessitates that all social systems actors take a new "look" at this phenomenon in the context of family and community care to improve the quality of life of orphans and foster parents in Tula Oblast. This interaction should be aimed at creating a positive relationship between children and parents that will restore (reanimate) the intergenerational continuity that has been disrupted in recent decades.

The region currently demonstrates the following trends characteristic of the entire system in the sphere of childhood:

- given all the objective reasons, it should be noted that the work of all agencies on solving the problems of a particular foster family is often delayed;

- active modern parents in need of constructive support in raising foster children remain outside of the focus of analytical research. This prevents society from reconsidering the nature of orphanhood, childhood and family life, and the role of family and parenthood in transferring positive social and cultural experiences, as well as hinders the identification of key areas of work to improve the quality of life for foster children and parents in the region;

- the programs for foster parents implemented in the educational institutions of the region should not be solely based on the standardized approach. All actors in social systems have to make better use of the socio-pedagogical approach through socio-cultural interaction involving the variability of models; 
- the identified prospects for further research in the area of interest include the development of educational and developmental multivariant programs for the development of the system of the upbringing of orphaned children.

\section{Acknowledgments}

The article was prepared with the support of the Government of Tula Oblast, grant in the field of science and technology, 2020, on the topic: "Tula regional policy regarding orphans and children left without parental care: history, state, and trends of development in the interests of the region" (Tula Oblast government resolution № 541 of September 10, 2020, contract № DC/169 of October 29, 2020)

\section{References}

1. I.S. Danilova, E.Ia. Orekhova, N.A. Shaidenko, Modern Scientist, 2, 136-141 (2017)

2. K.N. Polivanova, Psychological-Educational Studies, 7(3), 1-13 (2015). https://doi.org/10.17759/psyedu.2015070301

3. E.Ia. Orekhova, N.A. Shaidenko, A.V. Sergeeva, The Scientific Opinion, 6-7, 103-106 (2016)

4. J, McCarthy, R. Edwards, Issledovaniia semi: osnovnye poniatiia [Key Concepts in Family Studies] (Higher School of Economics Publishing House, Moscow, 2018)

5. M. Steinbach, M. Vatz Laaroussi, M. Potvin, Alterstice, Revue Internationale de la Recherche Interculturelle, 5(2), 99-108 (2016)

6. V. Terziev, E. Arabska, Monthly Scientific Journal Eurasian Union of Scientists (EUS), 2, 77-85 (2017)

7. Zh. Chernova, Gendernaia kultura i institutsionalnyi dizain kak matritsa issledovaniia semeinoi politiki [Gender culture and institutional design as a matrix for family policy research], in V. Shmidt, E. Iarskaia-Smirnova, Zh. Chernova (Eds.), Politika semi i detstva v postsotsializme, 36-52 ("Variant" LLC: Center for Social Policy and Gender Studies, Moscow, 2014)

8. European Commission/EACEA/Eurydice/Eurostat, Key Data on Early Childhood Education and Care in Europe. 2014 Edition. Eurydice and Eurostat Report. (Publications Office of the European Union, Luxemburg, 2014). https://doi.org/10.2797/75270

9. B.V. Sergeeva, R.K. Arakelyan, Historical and Social-Educational Idea, 8(1(1)), 184 188 (2016). https://doi.org/10.17748/2075-9908-2016-8-1/1-184-188

10. Decree of the Government of Tula Oblast of October 8, 2012, N 621-p "On the strategy for action in the interest of children of Tula Oblast in $2012-2017$ ". Accessed on: December 20, 2020. [Online]. Available: http://docs.cntd.ru/document/446100906

11. V.A. Anikin, Iu.P. Lezhnina, S.V. Mareeva, E.D. Slobodeniuk, Monitoring, 3(151), 345-366 (2019). https://doi.org/10.14515/monitoring.2019.3.19

12. I.F. Dementeva (Ed.), Semeinoe vospitanie v sovremennoi Rossii: sostoianie i strategiia razvitiia [Family upbringing in modern Russia: current status and development strategy], 152-153 (Institute for the Study of Childhood, Family, and Education of the Russian Academy of Education, Moscow, 2015)

13. E.A. Burina, A.E. Kudinova, Vestnik of Minin University, 8(1), 6 (2020).

https://doi.org/10.26795/2307-1281-2020-8-1-6 
14. A.V. Makhnach, T.Iu. Lotareva, South-Russian Journal of Social Studies, 2, 120-137 (2017)

15. F. Lorcerie, International Journal of School Climate and Violence Prevention, 2, 9-36 (2016) 